Atualidades de Pesquisa

\title{
PSICANÁLISE E EDUCAÇÃO: \\ INQUIETAÇÕES POLÍTICAS - UM \\ DEBATE A PARTIR DO ENCONTRO DA \\ PSICANÁLISE COM A EDUCAÇÃO \\ INFANTIL NO BRASIL
}

Tese de Doutorado na Faculdade de Educação da

Universidade de São Paulo

\author{
Autora \\ Paula Fontana Fonseca \\ Orientador \\ Prof. Dr. Rinaldo Voltolini \\ (Universidade de São Paulo)
}

Banca examinadora

Profa. Titular Maria Cristina Machado Kupfer (Universidade de São Paulo), Profa. Dra. Simone Zanon Moschen (Universidade Federal do Rio Grande do Sul), Prof. Titular Chistian Ingo Lenz Dunker

(Universidade de São Paulo), Prof. Dr. Paulo César Endo (Universidade de São Paulo) 
campo da Psicanálise e Educação se sustenta em um entendimento do educar como sendo da ordem de uma profissão impossível. Não há garantias de resultados, na medida em que a relação entre meios e fins não é previsível. É a partir desse pressuposto ético que se fez ouvir a questão acerca dos efeitos de uma política do analista no campo educativo. Para depreendermos um entendimento sobre o tema específico de uma política própria à psicanálise, estabelecemos um debate com autores contemporâneos que recortaram essa questão no escopo freudo-lacaniano. Ao trabalharmos com os discursos propostos por Lacan, acessamos as políticas próprias a cada um deles e empreendemos uma análise das políticas públicas em Educação Infantil tomando-os como operadores de leitura. Desse debate foram extraídos três eixos de análise - políticas assistencialistas, diagnósticas e preditivas - que evidenciaram que a educação infantil vem sendo agenciada predominantemente sob a égide do discurso universitário ou do capitalista na contemporaneidade. Demonstramos que a própria teoria psicanalítica também é apropriada em diversos momentos como mais um saber explicativo acerca dos impasses escolares e educativos, mas isso não se configura como um exemplo do agenciamento da política do analista. Apresentamos a articulação entre a ética e a política na psicanálise e fundamentamos que a política do discurso analítico visa permitir que o sujeito se separe de uma posição alienada a um saber que lhe é extrínseco. Assim, o psicanalista que trabalha na fronteira com a educação busca possibilitar que o educador se pergunte acerca desses saberes pedagógicos hegemônicos de modo a encontrar uma resposta singular que o autorize a se lançar na prática educativa, mesmo não havendo garantias de antemão dos resultados a serem alcançados. 